\title{
ENERGY PRICE SHOCKS AND DYNAMICS OF CURRENT ACCOUNT IN TURKEY: A FAVAR APPROACH
}

\section{DOI: 10.17261/Pressacademia.2019.1112}

JEFA- V.6-ISS.3-2019(3)-p.135-141

\section{Bige Kucukefe}

Namik Kemal University, M.Ereglisi, Tekirdag, Turkey.

bigekucukefe@nku.edu.tr, ORCID: 0000-0003-1945-3037

Date Received: May 15, 2019

Date Accepted: September 2, 2019

To cite this document

Kucukefe, B., (2019). Energy price shocks and dynamics of current account in Turkey: a FAVAR approach. Journal of Economics, Finance and Accounting (JEFA), V.6(3), p.135-141.

Permanent link to this document: http://doi.org/10.17261/Pressacademia.2019.1112

Copyright: Published by PressAcademia and limited licenced re-use rights only.

\section{ABSTRACT}

Purpose- In this article, we examine the linkages between current account and energy prices, namely crude oil, coal and natural gas in Turkey the years between 2005 and 2016.

Methodology- This article investigates how the changes in the energy prices affect the current account in Turkey. For this purpose, a FactorAugmented Vector Auto Regression (FAVAR) model is used with economic data from the Turkish economy and world commodity price indexes to obtain empirical results for current account dynamics in the Turkish economy. The impact of various factors that include crude oil prices, coal prices, natural gas prices and fuel (Energy) index (Crude oil, natural gas, and coal price indices) data have been studied by obtaining impulse response functions.

Findings- Natural gas prices gradually affect the current account. The impact is permanent after a period indicating a very limited elasticity. Oil prices have an immediate The current on the current account. Cycles, in the long run, indicate some degree of elasticity. The negative effect of coal price on the current account deficit occurs with a significant delay. Crude oil price index shocks graphs and fuel index, which includes oil price, coal price and natural gas, and crude oil price shocks graphs are very similar.

Conclusion- In this comprehensive study, we can conclude that crude oil prices, coal prices, natural gas prices deteriorate current account balance. From all of the energy indices, the crude oil price is the most effective on the current account.

Keywords: Current account, oil prices, FAVAR model, Turkish economy.

JEL Codes: C30, E30, F32, Q43

\section{INTRODUCTION}

Turkey has effected with oil prices heavily. Efforts to raise the growth rates of developing countries as well as developed countries have increased energy demand. Despite improvements in renewable energy sources, the largest share in energy consumption is $80 \%$ of the fossil fuels in the World (World Bank data). With the increase in demand for fossil fuels and political risks in oil-producing countries have led to fluctuations in energy prices since 1973. The impact of rising oil prices on economies has attracted the interest of economists especially after 1980 (Hamilton 1983, 1988, 1996, 2003, 2009; Hamilton and Herrera, 2004; Mork, 1989; Barsky and Kilian, 2004). Rises in oil prices affect new investments, trade, and output negatively by increasing production costs. After 1990, the world faced rapid economic growth, especially in China and India. According to the U.S. Energy Information Agency, China became the world largest net importer of oil and also became the largest primary energy consumer in 2016. Under the influence of the Iraq war, oil prices started to increase in 2003. Rising oil prices and price shocks in the 2007-2008 period hits current accounts in oil importer developing countries. In contrast, lower oil prices limit the current account deficit in developing countries as well as in Turkey after 2015.

Current Account as the primary account of the balance of payments shows the financial needs or savings in a country. Turkey, like many other developing countries, generates a current account deficit generally. In a current account deficit, the economy borrows from other countries and invests more than its savings. Turkey has current account deficit mostly except for a couple of crisis years. We can see clearly the relationship between crude oil prices and current account in Figure 1. Higher oil prices pushed Turkey's current account deficit in 2011 to its widest in over sixteen years. 
Figure 1: Current Account and Oil Prices in Turkey

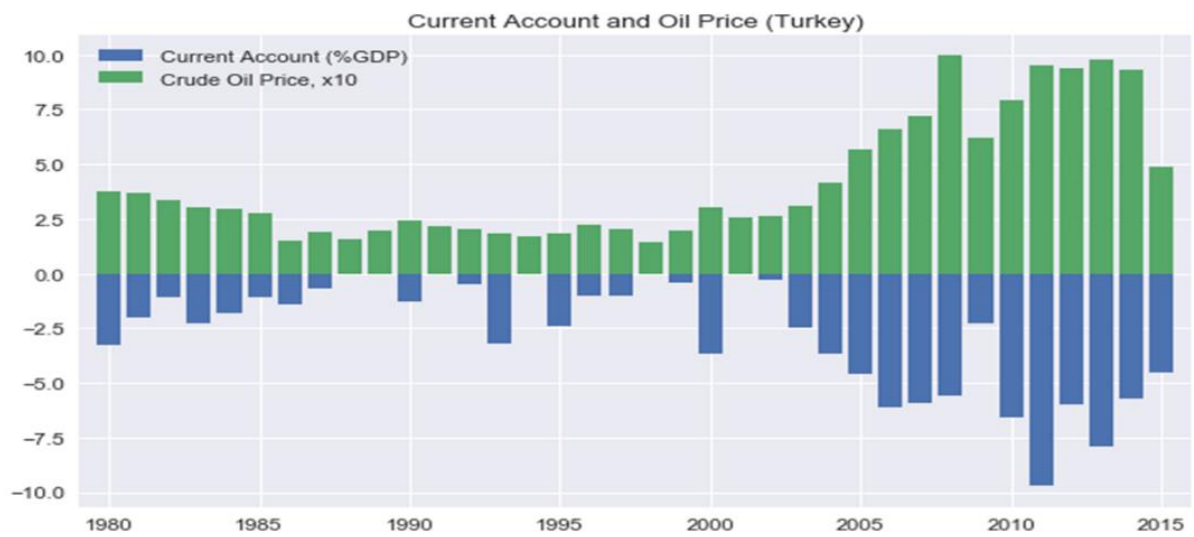

Turkey has long been oil importer country dealing with of current account deficit and so that Turkey is a good "Small Open Economy" example for investigating oil prices and current account. For this reason, this topic has recently attracted the interest of researchers. To the knowledge of the author, it is the first time that a FAVAR model used for investigating oil, coal, natural gas prices, fuel (Energy) index (Crude oil, natural gas, and coal price indices) and current account relationship.

\section{LITERATURE REVIEW}

Despite the importance of developing countries, there is a limited study that analyzed the relationship between current account and oil price for developing countries. Vidal and Ruiz (2016) use panel data to estimate the effect of oil price slump after 2014 on structural and cyclical current account in 98 countries. According to this study, Turkey is one of the most benefited countries regarding cyclical effects. Oil exporter countries structurally damaged with this oil price decrease. Barnett and Straub (2008) used the structural VAR approach to identify the impact of monetary policy, private absorption, technology, and oil price shocks on the current account fluctuations in the United States. According to the study, monetary policy shocks and private absorption shocks had a much more important role than oil prices on the deterioration in Current Account in the USA over time. Ang and Sek (2011) used Generalized methods of moments analyzing the determinants of current account dynamics in ten economies from 1973 to 2010. Besides world oil prices, interest rate, the exchange rate and consumer price index are the major determinants of the current account deficit. Qurat-ul-Ain and Tufail (2013), aims to research dynamic relationship between current account and exchange rate for D-8 countries for 1981-2010 years. They used Vector Autoregression for their research. Longe, Adelokun and Omitogun (2018) used a time series to find a nexus between current account and oil prices in Nigeria.

Erdogan and Bozkurt (2009) carried out MGARCH methodology for estimating the determinants of the current account deficit in Turkey. In this study, oil prices are still very decisive. M2, export/import coverage ratio, inflation, inflation uncertainty, exchange rate, exchange rate uncertainty, and share of foreign direct investment in GDP are the other determinants of the current account deficit. Özlale and Pekkurnaz (2010) identified net effect of oil prices on the current account balances for the Turkish economy using a structural vector autoregression model. Kayikci (2012) using VAR analysis, examined the linkages between inflation, growth, openness, oil prices, and appreciation of the real exchange rate and the current account deficit in Turkey in 1987-2009. Ozata (2014), examined sustainability of current account deficit with high oil prices using Structural Vector-Autoregression (SVAR) in Turkey. Uysal, Yılmaz and Tas (2015) used VAR analysis to explain energy import and current account deficit in Turkey. Basarır and Ercakar (2016) also used VAR analysis to investigate the effect of crude oil prices and exchange rates on the current account. Bayraktar, Taha and Yıldız (2016) determined the impact of oil prices in the FragileFive countries (Brazil, Indonesia, South Africa, India, and Turkey) on current account deficit and growth using the method of panel data analysis. They also found a meaningful relationship in oil prices with both GDP and the current account deficit. Besel (2017) used Gregory-Hansen Cointegration Test and Toda-Yamamoto Causality Test to investigate oil prices and current account deficit dynamics. Yalta and Yalta (2017) used a maximum entropy bootstrap method to calculate dependency on imported oil and its effects on the current account. Berk and Cin (2018) investigated a relation ship between energy consumption, population and current account deficit is analyzed by using Granger causality analysis, Augmented Dickey Fuller (ADF) Unit Roots Test", Vector Autoregression (VAR) and Vector Error Correction Models (VECM). 


\section{DATA AND METHODOLOGY}

\subsection{FAVAR Method}

The Factor-Augmented VAR (FAVAR) method, developed by Bernanke, Boivin and Eliasz (2005), has distinct advantages over the standard VAR. The FAVAR method is based on the Dynamic Factor Models (DFM), developed by Geweke (1977). With FAVAR, large macroeconomic time series can be summarized by a relatively small number of prediction 'factors'. FAVAR can predict the macroeconomic factors that occur in large data sets systematically and consistently. In this respect, the FAVAR method is a natural solution to the degrees-of-freedom problem in the VAR analysis (Bagzibagli, 2012). Also, impulse response functions for a large number of variables can be obtained by the FAVAR method, and factors that cannot be represented by a single time series (such as economic activity) can also be included in the model. FAVAR method is widely used in many economic types of research today. If a small number of forecasting factors can effectively summarize large amounts of information about an economy, with the help of increasing the number of standard VAR using forecasting factors could be a solution to the degrees-of-freedom problem in VAR analysis.

To explain the FAVAR method, let us assume is an observable economic variables vector with size Mx1 and these variables has a widespread influence on the economy. In this stage, the aim may be to reveal or predict the structural relationship between variables. If our aim is only to uncover structural relationships between variables, we can follow standard methods and continue with a VAR approach, structural VAR (SVAR) or other multivariate time series estimation models using. However, in many applications, there may be additional unobservable but important economic information that is not included in. Let us suppose that we can summarize this additional information with $\mathrm{Kx1}$ vector, , For example, "economic activity" or "credit conditions" are factors that cannot be observed. These factors, which we cannot easily represent with one or two series, affect the overall economy.

Assume that the joint dynamics of (Ft, $\mathrm{Yt}$ ) are defined by:

$$
\left[\begin{array}{l}
F_{t} \\
Y_{t}
\end{array}\right]=\Phi(L)\left[\begin{array}{l}
F_{t-1} \\
Y_{t-1}
\end{array}\right]+v_{t}
$$

where $\Phi(L)$ is a lag polynomial of order d, which may contain a priori restrictions as in the structural VAR studies. $v_{t}$ is the zero-mean error term with covariance matrix $Q$.

Equation (1) is a factor-augmented vector autoregression (FAVAR) and therefore, there is a direct mapping into the existing VAR results and provides a way of assessing the marginal contribution of the information included in $F_{t}$. Besides, Equation (1) will, in general lead to biased estimates of the VAR coefficients and impulse response coefficients if the true system is a FAVAR. Because the factors $F_{t}$ are not observable, Equation (1) cannot be directly estimated. On the other hand, if the factors representing forces that potentially affect many economic variables are interpreted, it is possible to infer something about the factors from observations on a range of economic time series data. For example, suppose that we have a number of informational time series, denoted by vector $X_{t}$ with size $N$. The number of informational time series $(N)$ is greater than $T$, the number of time periods and much greater than the number of factors $(K+M \ll N)$.

Assume that the informational time series $\left(X_{t}\right)$ are related to the unobservable factors $\left(F_{t}\right)$ and observable factors $\left(Y_{t}\right)$ by:

$$
X_{t}^{\prime}=\Delta^{f} F_{t}^{\prime}+\Delta^{y} Y_{t}^{\prime}+e_{t}^{\prime}
$$

where $\Delta^{f}$ is a $N \times K$ matrix of factor loadings, $\Delta^{y}$ is a $N \times M$ matrix and $e_{t}{ }^{\prime}$ is the error vector of length $N$ with zero mean and will be assumed either uncorrelated or weakly correlated, depending on the estimation method (principal components or likelihood methods). Equation (2) employs the idea that both $Y_{t}$ and $F_{t}$ can be generally correlated and represent pervasive forces driving the common dynamics of $X_{t}$ which are thus noisy measures of the underlying unobserved factors $F_{t}$ conditional on the $Y_{t}$. We estimate (1) and (2) with the help of the two-step principal component approach.

\subsection{Data}

The dataset in this study consists of 50 items and is provided from the IMF, World Bank, CBRT, www.tradingeconomics.com website and TURKSTAT (Turkish Statistical Institute) data sources. The data set consists of monthly data covering the period January 2005 - December 2016 and given in Appendix-1. In addition to Turkish economy data such as the TUFE index, CBRT interest rate, CBRT foreign reserves, unemployment rate and current account, consumer price index, BIST XU100 (USD,EUR), production of otomotive, world commodity price indexes such as oil, natural gas and cotton, 1 ons gold sales price, are included in the dataset. 
We implemented the Augmented Dickey-Fuller Test (ADF) to the dataset in MATLAB. Level difference and logarithmic difference transformations are applied to make the dataset stationary. ADF test results and $p$-values after the applied transformations. Since the items in the data set are in different sizes and units, the standardization process is used before they are used in the model. After the arithmetic means is subtracted from the time series value and the difference is divided by the standard deviation, the new series average is zero and the standard deviation is one.

\section{FINDINGS}

In this section, crude oil prices, coal prices, natural gas prices are used to investigate the main factors affecting the current account. We present impulse response functions to examine the effects of these variables on the current balance. The magnitude of the shock value is the standard deviation of the selected variable. Plus or minus sign of the shock value determines the direction of the impulse response function according to the equilibrium point, but these responses are symmetrical to the equilibrium position. In other words, the absolute value of the reactions is the same.

\subsection{International Crude Oil Prices}

The IMF crude oil index POILAPSP is calculated by taking simple averages of the three spot prices (Brent, West Texas Intermediate and Dubai Fateh). Figure- 2 shows the current account changes following an increase in oil prices in the FAVAR model. For Turkey, where oil is a primary import commodity, an increase in oil prices has an impact on the current balance minus. It is evident from Figure- 2 that oil prices are inversely proportional to the current account deficit in Turkey. The magnitude of the effect increases for approximately 20 periods, decreases after reaching its maximum value and oscillates around an average of -0.04 .

Figure 2: The Impact of One Standard Deviation Increase in International Oil Price Index on the Current Account Balance

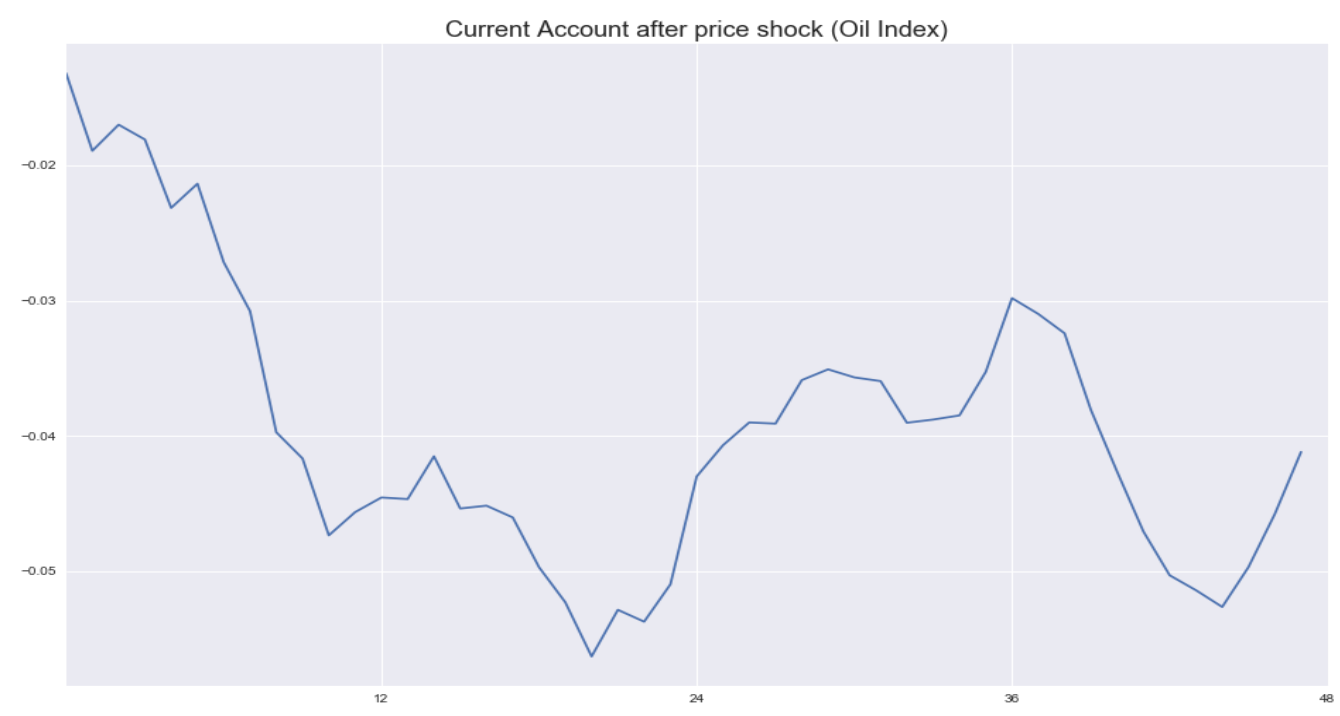

The spread of effect size over time may be due to two factors. The first is the time lag between the spot price of petroleum and the price on the date of import (2-3 months), and the other is the time for price adjustments of imported goods, which are partly dependent on oil prices, such as natural gas. Moreover, the decrease in demand after the increase in the price of petroleum products may explain the upward movement after the 20th period.

\subsection{Coal Prices}

Coal Price Index data is taken from www.tradingeconomics.com website. An increase in international coal price will not affect current account deficit in the first ten periods as shown in Figure 3. One explanation for this is that local coal resources can substitute the imported coal. We see clearly from the graph that there is a time lag between an increase in international coal price and its effect the on current account. On the other hand, current account deficit grows significantly after the tenth period. 
Figure 3: The Impact of One Standard Deviation Increase in Coal Prices on the Current Account Balance

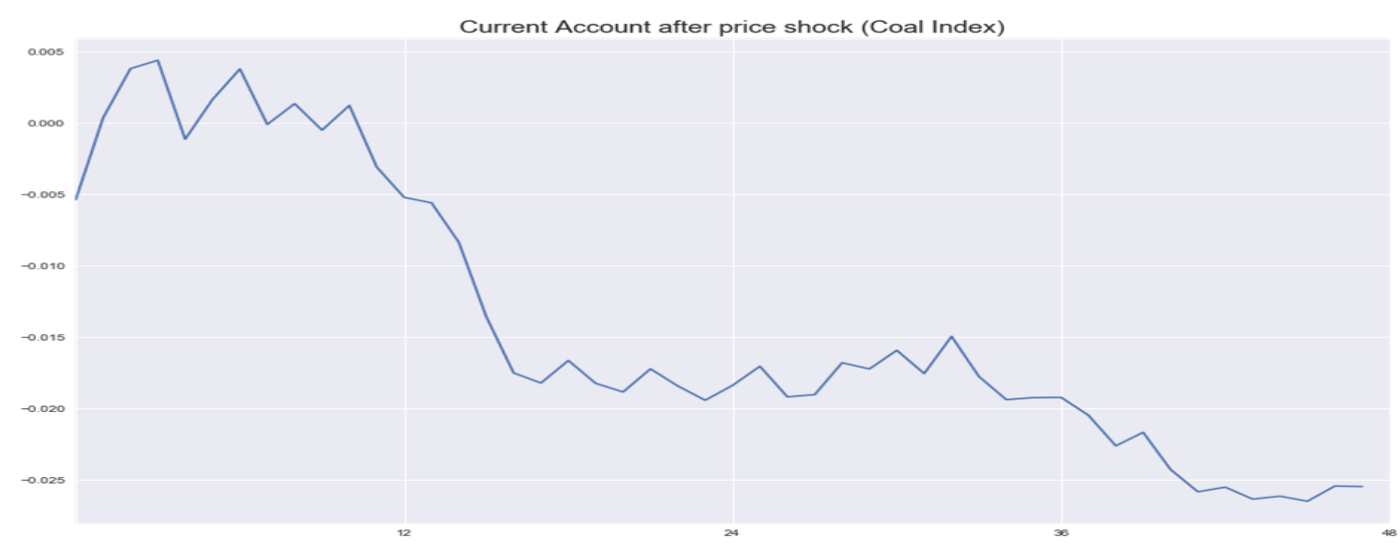

\subsection{Natural Gas Price}

Natural gas price (Russian Natural Gas border price in Germany) data is taken from www.tradingeconomics.com website. An increase in international natural gas price will affect the current account in minus direction and after ten periods this change becomes permanent as shown in Figure 4.

Figure 4: The Impact of One Standard Deviation Increase in International Natural Gas Price on the Current Account Balance

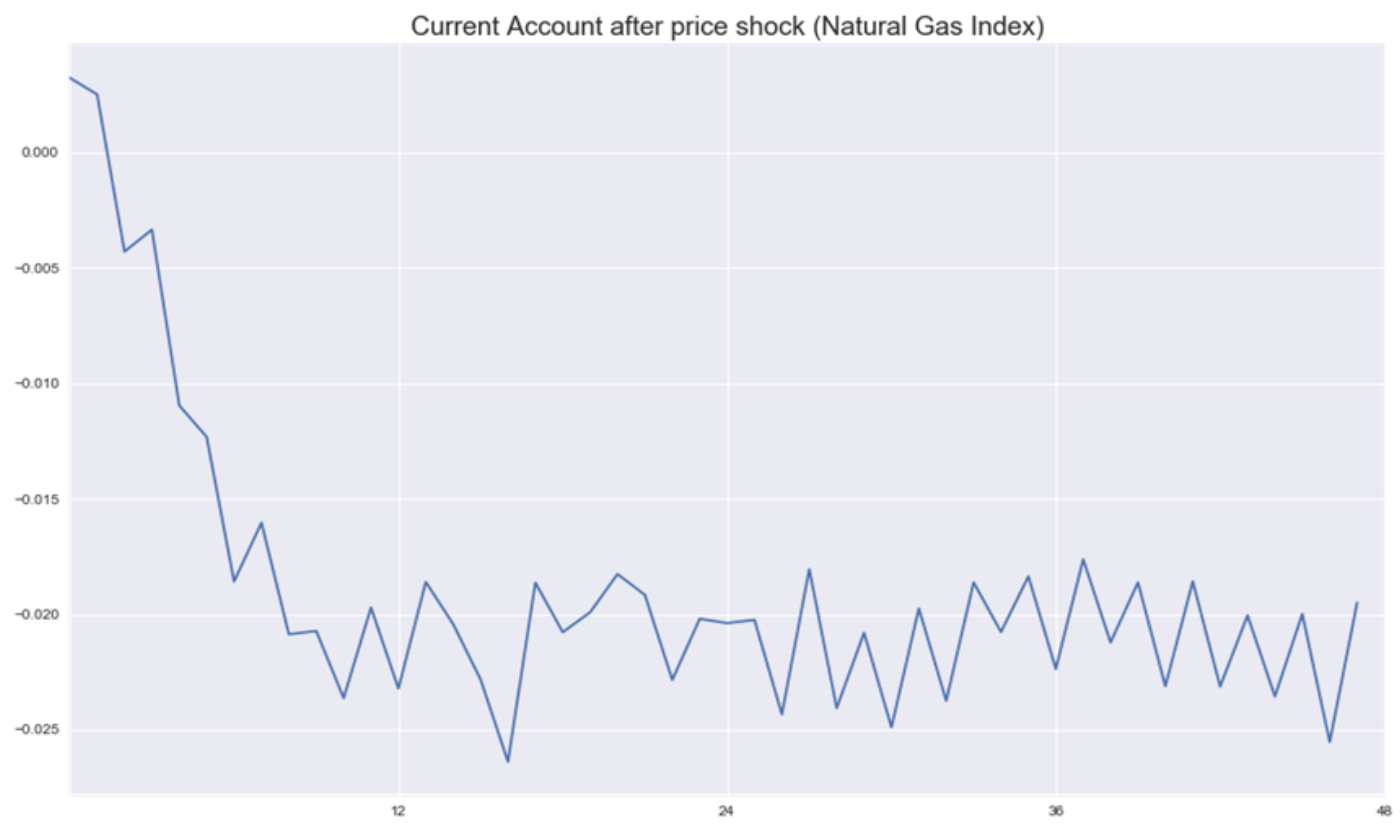

4.4. Fuel (Energy) Index, $(2005=100)$, Crude oil, natural gas, and coal price indices

Fuel (Energy) index, Crude oil, natural gas, and coal price indices data is taken from www.tradingeconomics.com website. This fuel index includes primary energy resources used in Turkey. Figure 5 depicts the current balance following an increase in fuel prices in the FAVAR model. An increase in international fuel price will affect current account in minus direction as expected. There is a reversal after the period 20 followed by another reversal at 36th period indicating preference adjustments by consumers. 
Figure 5: The Impact of One Standard Deviation Increase in Fuel (Energy) Index (crude oil, natural gas, and coal price indices) on the Current Account Balance

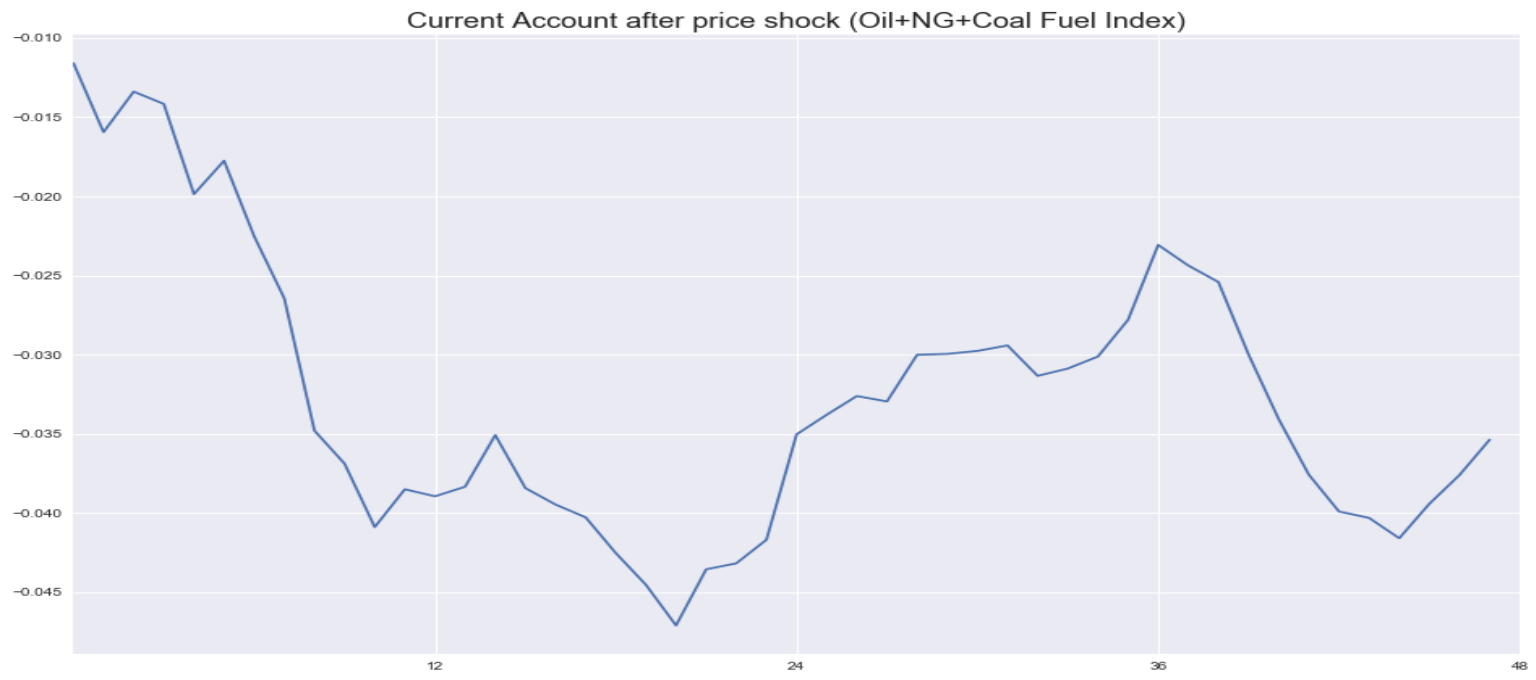

\section{CONCLUSION}

In this study, we investigate the impact of the crude oil prices, coal prices, natural gas prices on current account dynamics of the Turkish economy. For this purpose, a FAVAR model was used. The dataset included in the FAVAR model covers the period from January 2005 to December 2016 and consists of 50 items. In addition to data such as the consumer price index, unemployment rate and industrial production index of the Turkish economy, world commodity price indices such as crude oil, natural gas and cotton are also included in the dataset. Impulse response functions were obtained to examine different fuel prices affecting the current account dynamics. In this comprehensive study crude oil prices, coal prices, natural gas prices deteriorate current account balance. Natural gas prices gradually affect the current account. The impact is permanent after a period indicating a very limited elasticity. Oil prices have an immediate impact on the current account. Cycles, in the long run, indicate some degree of elasticity. The negative effect of coal price on the current account deficit occurs with a significant delay. We can conclude that, from all of the energy indices, the crude oil price is the most effective on the current account.

\section{REFERENCES}

Ang, H. Y., Sek, S. K. (2011). Empirical Investigation on the Determinants of Current Account Balances. International Journal of Advanced Computer Sciences 1(4): 146-151.

Bagzibagli, K., (2012). Monetary Transmission Mechanism And Time Variation In The Euro Area. Department Of Economics Discussion Paper, 12-12. University Of Birmingham

Barnett, A., Straub, R. 2008. What Drives U.S. Current Account Fluctuations? European Central Bank Working Paper Series, No.959.

Barsky, R. B. \& Kilian, L. (2004). Oil and Macroeconomy Since the 1970s. Journal of Economic Perspectives,18(4), 115-134.

Basarır, Ç., Erkaçar, M. E. (2016). An Analysis of the Relationship between Crude Oil Prices. Current Account Deficit and Exchange Rates: Turkish Experiment. International Journal of Economics and Finance, Vol. 8, No. 11.

Bayraktar, Y., Taha, E., Yıldız, F. (2016). A causal relationship between oil prices current account deficit, and economic growth: an empirical analysis from fragile five countries, Ecoforum Journal 5 (3).

Berk, C., Cin, K. O. (2018). On Energy Dependence, Current Account Deficit and Population in Turkey. Open Journal of Business and Management, 6, 183-192.

Bernanke, B., Boivin, J., Eliasz, P. (2005). Measuring the Effects of Monetary Policy: A Factor-Augmented Vector Autoregressive (FAVAR) Approach. Quarterly Journal of Economics, 120(1), 387-422.

Besel, F. (2017). Oil Prices Affect Current Account Deficit: Empirical Evidence from Turkey. Journal of Applied Research in Finance and Economics, v. 3, n. 2, p. 13-21. 
Corden, W.M. (1994). Does the Current Account Matter?. Economic Policy, Exchange Rates and the International System, W.M. Corden, University of Chicago Press.

Erdogan, S., Bozkurt, H. 2009. Turkiye'de Cari Acigin Belirleyicileri: MGARCH Modelleri ile Bir Inceleme, Maliye Finans Yazilari 23(84): 135172.

Geweke, J. (1977). The Dynamic Factor Analysis of Economic Time Series Models, Social System Research Institute, University of Wisconsin Madison

Hamilton, J. D. (1983). Oil and Macroeconomy since World War II. Journal of Political Economy, 91, 228-248.

Hamilton, J. D. (1988). Are the macroeconomic effect of oil-price changes symmetric? A comment. Carniege-Rochester Conference Series

Hamilton, J. D. (1996). That Is What Happened to The Oil Price-Macroeconomy Relationship. Journal of Monetary Economics, 38 (1996), 215220.

Hamilton J. D, (2003). What is an oil shock? Journal of Econometrics. 113(2), 363-398.

Hamilton J. D., Herrera A. M. (2004). Oil Shocks and Aggregate Macroeconomic Behavior: The Role of Monetary Policy: Comment. Journal of Money, Credit and Banking 36(2): 265-286.

Kayikci, F. (2012). Determinants of the Current Account Balance in Turkey: Vector Auto Regression (VAR) Approach. African Journal of Business Management, 6(17): 5725-5736.

Kilian, L. (2009), Not All Oil Price Shocks Are Alike: Disentangling Demand And Supply Shocks In The Crude Oil Market. American Economic Review, 99(3): 1053-1069.

Longe, A.E., Adelokun, O., Omitogun, O. (2018). The Current Account and Oil Price Fluctations Nexus in Nigeria. Journal of Competitiveness, Vol. 10, Issue 2, pp. $118-131$.

Özata, E. (2014). Sustainability of Current Account Deficit with High Oil Prices: Evidence from Turkey. International Journal of Economic Sciences, 3(2), 71-88.

Özlale, Ü., Pekkurnaz, D. (2010). Oil Prices and Current Account: A Structural Analysis for the Turkish Economy. Energy Policy, 38, $4489-4496$.

Qurat-ul-Ain, S., Tufail, S. (2013). The effect of Oil Price Shocks on the Dynamic Relationship Between Current Account and Exchange Rate:Evidence From D-8. The Pakistan Development Review, Vol. 52, No. 4,

Uysal, D., Yılmaz, K. Ç., Taş, T. (2015). Enerji İthalatı ve Cari Açık Ilişkisi: Türkiye Örneği. Muş Alpaslan Üniversitesi Sosyal Bilimler Dergisi, v. 3, n. 1, p.63-78.

Vidal, O. A., Ruiz, A.U. (2016). The Current Account Balance and the Oil Price Shock. BBVA Research Emerging Markets Economic Watch, Economic Analysis, April 2016

Yalta, Y.A., Yalta, A. T. (2017). Dependency on Imported Oil and Its Effects on Current Account, Energy Sources, Part B: Economics, Planning, and Policy, Vol.12, No:10, 859-867. 